\title{
Chapter 3 \\ Targets for the Reorganisation \\ of the Investment Protection Regime
}

A reorganisation of the investment protection regime by introducing a two-tiered court system or a multilateral appellate body could offer advantages in comparison to the current system. ${ }^{1}$ In a first step, the expected positive effects of the new approach are discussed. In a second step, the two options of a two-tiered MIC and a MIAM are compared based on the outcomes of the previous discussion.

\subsection{Positive Effects of a New Approach}

Depending on the design of the system, it appears possible through enhanced institutionalization $^{2}$ to achieve greater consistency of decisions, to reinforce the independence and neutrality of adjudicators, to improve expedience of investment disputes, to limit costs for the parties involved, to ensure more accessibility for Small and Medium Enterprises (SMEs) and finally, to offer greater transparency than in current ISDS. ${ }^{3}$ These aspects are also related to the increased emphasis on the rule of law-according to Articles 2 and 21 TEU. $^{4}$

An international investment court, in the sense of a permanent institutional court, can facilitate streamlined procedures through its efficient organisation. The organs of the court may deliver summons, execute the serving of documents and offer its premises for negotiations and translation services, including simultaneous interpretation. This can also reduce procedural problems which may occur if, for example,

\footnotetext{
${ }^{1}$ On this see also, European Union (2019), para. 40.

${ }^{2}$ Hereto in particular Schill (2015).

${ }^{3}$ European Union (2019), paras. 40 et seqq. A discussion on the problems which the EU seeks to solve through the ICS and MIC can be seen in Alvarez Zarate (2018), pp. 2767 et seqq.

${ }^{4}$ Also emphasised in European Commission (2017), p. 38.
} 
the parties prefer not to make use of the services of the International Centre for Settlement of Investment Disputes (ICSID) Secretariat, the International Criminal Court or the Permanent Court of Arbitration (PCA). In addition, the MIC proposed here can provide its own procedural rules, adapted to the specific needs of the disputes, and can envisage its own mechanism for the implementation (recognition and enforcement) of its decisions. ${ }^{5}$

\subsubsection{Consistency of Decisions}

52 Nowadays, a large number of arbitral awards are publicly available and they facilitate the interpretation of individual clauses of investment protection treaties in future cases. ${ }^{6}$ These awards are often said to be inconsistent—even in cases with identical facts. ${ }^{7}$ Even substantive protection standards with nearly identical wording have been interpreted in a contradictory manner in individual cases, ${ }^{8}$ such as the applicability of the most-favored nation clause to procedural provisions in other IIAs of the host state, ${ }^{9}$ the scope of so-called umbrella clauses ${ }^{10}$ or the attribution of umbrella clauses, ${ }^{11}$ but also rules of procedure, like the possibility of a waiver of rights. ${ }^{12}$ At the same time, however, it is noteworthy that a consistent application of many substantive as well as procedural investment law standards has evolved. This is remarkable considering the lack of binding precedence of arbitral awards, the absence of review through an appeal mechanism and the diverging compositions of the benches of arbitral tribunals. What is clear is that a smaller group of judges, as well as an appeals mechanism can help to prevent inconsistent decisions. ${ }^{13}$ In fact, a standing court with a permanent pool of judges can lead to a higher degree of

\footnotetext{
${ }^{5}$ On this see also, European Union (2019), para. 30.

${ }^{6}$ Publications of decisions and the status of individual proceedings on the ICSID website, https:// icsid.worldbank.org/apps/ICSIDWEB/cases/Pages/AdvancedSearch.aspx.

${ }^{7}$ Cf. for instance CME v. Czech Republic and Lauder v. Czech Republic; see thereto Carver (2004), pp. 23 et seqq.

${ }^{8} \mathrm{Cf}$. thereto in detail Griebel and Kim (2007), pp. 188 et seqq.

${ }^{9}$ On the application of the most-favoured nation (MFN) clause to dispute settlement agreements, cf. Maffezini-decision on the one hand and Plama v. Bulgaria on the other hand; thereto Schill (2016), pp. 251 et seqq.; Gaillard (2005); Douglas (2011), p. 97; Maupin (2011), p. 157; Paparinskis (2011), pp. 14 et seqq.

${ }^{10}$ Cf. thereto $S G S$ v. Pakistan, ICSID Case No. ARB/01/13 and SGS v. Philippines, ICSID Case No. ARB/02/6; thereto also Alexandrov (2004), pp. 555 et seqq.; Chung (2007), pp. 961 et seqq.; Schreuer (2004), pp. 231 et seqq.; Sinclair (2004), pp. 411 et seqq.; Wälde (2005), pp. 183 et seqq.

${ }^{11}$ See thereto in particular Noble Ventures v. Romania, ICSID Case No. ARB/01/11.

${ }^{12} \mathrm{Cf}$. thereto for instance $S G S$ v. Philippines, ICSID Case No. ARB/02/6 on the one hand and $L A N C O$ v. Argentina, ICSID Case No. ARB/97/6 on the other hand; see also European Union (2017), paras. 22 et seqq.

${ }^{13}$ See also European Union (2019), paras. 43 et seqq.; European Commission (2017), p. 39.
} 
jurisprudential consistency, even without binding precedence. ${ }^{14}$ In any event, binding precedence could not be based on inconsistent interpretations of or diverging substantive law.

Proper consistency of judicial decisions can only be achieved if a multilateralisation of the substantive law, as the basis of the decisions, is also implemented. Nevertheless, the presence of permanent judges as well as a consultation mechanism between judges of different chambers can prevent contradictory decisions (see paras. 119 et seqq.).

\subsubsection{Greater Legitimacy}

The current discussion also invokes the question of sufficient legitimacy and control of international dispute resolution. Without engaging in the discussion as to whether this criticism is justified, ${ }^{15}$ it is said that judges can enjoy a high degree of legitimacy at international courts if they have passed a predetermined selection process and have ultimately been elected or confirmed by states. ${ }^{16}$ Therefore, guidelines, in particular those of the Council of Europe, should play a special role when designing a new institution. ${ }^{17}$ This would add to the legitimacy of the judges through the selection process in addition to the legitimacy derived from the international treaty on which the dispute settlement is based.

\subsubsection{Independence and Neutrality of Judges}

Arbitrators have recently been repeatedly accused of a lack of independence and neutrality ${ }^{18}$ since they are at least partly appointed by private claimants and sometimes act as legal counsel in other proceedings. ${ }^{19}$ In addition, they are often accused of showing an investor-friendly attitude. ${ }^{20}$ The validity of the latter point has not

\footnotetext{
${ }^{14}$ For similar views, see, European Union (2019), para. 41; European Union (2017), para. 7; European Commission (2017), p. 28; Howard (2017), pp. 32 et seqq.

${ }^{15} \mathrm{Cf}$. thereto inter alia Steinbach (2016), pp. 1 et seqq.

${ }^{16}$ See for instance von Bogdandy and Krenn (2015), p. 420; von Bogdandy and Venzke (2012), pp. 32 et seqq. See also European Commission (2017), p. 46; European Union (2019), para. 22.

${ }^{17}$ Parliamentary Assembly of the Council of Europe, Committee on the Election of Judges to the European Court of Human Rights, Procedure for electing judges to the European Court of Human Rights, Information document prepared by the Secretariat of 21.2.2017, AS/Cdh/Inf(2017)rev3.

${ }^{18}$ Cf. UNCTAD (2013), p. 4; Eberhardt (2014), p. 3; Schill (2017), p. 2; European Union (2019), para. 6(ii); UNCITRAL (2018b), paras. 66 et seqq.; European Commission (2017), p. 28.

${ }^{19}$ Cf. UNCTAD (2013), p. 4; Paulsson (2010), pp. 339 et seqq.

${ }^{20}$ Cf. van Harten (2010), pp. 441 and 445; Brower and Schill (2009), p. 489: "arbitrators 'will be influence[d] by their self interest in reappointed in future cases'."
} 
been proven empirically. ${ }^{21}$ Furthermore, the generally applicable International Bar Association (IBA) Guidelines on Conflicts of Interest in International Arbitration ${ }^{22}$ set relatively high standards for the independence and impartiality of arbitrators. Notwithstanding these guidelines, these concerns could be further diminished by reforms if judges are appointed by states in advance, independent of a specific dispute, and for a long period of time. ${ }^{23}$ It is generally acknowledged that a permanent court with permanent judges would strengthen independence and neutrality. ${ }^{24}$

\subsubsection{Lack of a Control Mechanism}

56 In connection with the independence of the arbitrators, the problem of a non-existent or very limited control mechanism is often mentioned, ${ }^{25}$ which can lead to the above-mentioned inconsistent jurisprudence and lack of control by certain stakeholders. Formally, an appellate body can review erroneous or questionable decisions on procedural or substantive aspects of a case. ${ }^{26}$ The mere possibility of such a review would presumably increase the legitimacy of decisions in ISDS.

\subsubsection{Cost Efficiency}

57 International arbitration proceedings may lead to considerable costs. ${ }^{27}$ According to the Organisation for Economic Cooperation and Development (OECD), the average total procedural costs (including legal counsel costs) are around US\$8 million per case. ${ }^{28}$ Besides the procedural costs in the sense of the term defined in arbitration law, such as costs for the arbitrators, interpreters and secretariats, legal fees and other costs accrued for the representation of the parties, there are also other costs for legal experts and other experts for the calculation of damages. In current arbitration

\footnotetext{
${ }^{21}$ Wuschka (2015); Franck (2009), pp. 435 et seqq. Similarly, Alvarado Garzón (2019), p. 484.

${ }^{22}$ IBA Guidelines on Conflicts of Interest in International Arbitration, Resolution of the International Bar Association Council of 23.10.2014.

${ }^{23}$ European Union (2019), paras. 18 et seqq.

${ }^{24}$ Cf. van Harten (2008), pp. 21 et seqq.; Howard (2017), pp. 26 et seq.; European Union (2019), para. 47; see also, European Union (2017), para. 8.

${ }^{25}$ Hueckel (2012), p. 611; Chung (2007), pp. 967 et seqq.; UNCTAD (2013), pp. 3 et seq. Similarly, Alvarado Garzón (2019), p. 488.

${ }^{26}$ On this see also UNCITRAL (2018a), para. 40; for a discussion on scope of review see, European Union (2019), para. 14; European Commission (2017), p. 48.

${ }^{27}$ European Union (2017), paras. 33 et seq.; European Commission (2017), p. 14.

${ }^{28}$ Gaukrodger and Gordon (2012), p. 19.
} 
practice, tribunals are hesitant to order a full assumption of these costs by the losing party. $^{29}$

In spite of an increase in arbitration proceedings, investor-state arbitration is not an everyday instrument for redressing violations of investment law due to the high costs of the procedures. SMEs in particular have problems to cover the costs of investor-state arbitration. ${ }^{30}$ In addition, they cannot rely on compensation of their expenses for the arbitration even if they win the case.

Apart from financial risks for the plaintiffs, the high costs are also an enormous burden for developing countries. ${ }^{31}$ Accordingly, it is argued that states have to bear high costs for their defense, which can lead to a regulatory chill even in the event that they win the case. Therefore as a starting point and in the interest of a more efficient and cost-effective procedure, the establishment of an Advisory Center should be considered. ${ }^{32}$ Furthermore, a limitation of the object of dispute, the introduction of a principle of official investigation and by the possibility of imposing a limitation on the 'necessary costs' etc. could lead to a reduction of procedural costs.

\subsubsection{Access for SMEs}

As just pointed out, the question of cost-efficiency is directly related to the access for SMEs to investment protection. ${ }^{33}$ On the one hand, the access of SMEs to investment protection is currently considered desirable. ${ }^{34}$ On the other hand, so-called Third-Party Funding, mass as well as class actions etc. are considered extremely problematic developments in international investment protection. ${ }^{35}$ A new multilateral institution could constitute an opportunity to make institutionalized investment protection 'more suitable' for SMEs, for example through cost reduction, access to legal aid and/or procedural support through an advisory center and the acceleration of proceedings. A further possibility would be to allow class actions by SMEs and individual investors with respect to identical claims. ${ }^{36}$

\footnotetext{
${ }^{29}$ Hodgson (2015), pp. 749 et seqq.

${ }^{30}$ European Union (2017), para. 34; UNCITRAL (2018b), para. 111; European Commission (2017), p. 53.

${ }^{31}$ UNCITRAL (2018c), paras. 8 and 94; UNCITRAL (2018b), para. 111.

${ }^{32}$ On this see also UNCITRAL (2018c), para. 101; UNCITRAL (2018b), para. 119; UNCITRAL (2018a), para. 149; European Commission (2017), p. 54.

${ }^{33}$ See on this also CJEU, Opinion 1/17 of 30 April 2019, ECLI:EU:C:2019:341, paras. 205 et seqq.

${ }^{34}$ UNCITRAL (2018b), para. 131.

${ }^{35}$ Cf. Hindelang (2015), p. 20; See also, UNCITRAL (2019), para. 16.

${ }^{36}$ On this see also UNCITRAL (2018a), Annex. p. 15.
} 


\subsubsection{Transparency}

61 The majority of existing IIAs do not require any public access to procedures (even though decisions of the arbitral tribunals are generally published), resulting in the allegation of a lack of transparency dominating the current criticism and discussion. ${ }^{37}$ The Mauritius Convention ${ }^{38}$ adopted by the UN General Assembly in 2014 should ensure greater transparency going forward. With this convention, the UNCITRAL transparency rules ${ }^{39}$ will be extended to existing IIAs. ${ }^{40}$ These rules require inter alia public hearings and the publishing of essential procedural documents (memoranda, decisions) of investor-state arbitration proceedings. To date, the Mauritius Convention has been signed by 23 states (including Germany), ratified by five states (Cameroon, Canada, the Gambia, Mauritius and Switzerland) and entered into force on 18 October 2017. ${ }^{41}$ The European Parliament has also called for increasing transparency. ${ }^{42}$ Possible future models should explicitly take these recent developments in transparency into account in their procedural rules - as was done in the CETA, and planned for in the EU-Mexico Global Agreement and the EU-Vietnam IPA. ${ }^{43}$

\subsubsection{Time Efficiency}

62 The long duration of arbitration proceedings is being increasingly criticised, particularly due to the heavy workload of arbitrators. ${ }^{44}$ Compared to WTO Dispute Settlement Procedures (with an average of 15 months for the panel procedure and

\footnotetext{
${ }^{37}$ Cf. for instance UNCTAD (2013), p. 3; European Union (2017), para. 35; European Commission (2017), p. 15; Peterson (2001), p. 13; Schill (2011), p. 66; Bastin (2012), pp. 223 et seq., 227; Public Statement on the International Investment Regime-31 August 2010, http://www.osgoode.yorku. ca/public-statement-international-investment-regime-31-august-2010/; Wuschka (2016), pp. 32 et seqq.

${ }^{38}$ United Nations Convention on Transparency in Treaty-based Investor-State Arbitration (the Mauritius Convention on Transparency), which was adopted on 10.12.2014 and entered into force on 18.10.2017.

${ }^{39}$ UNCITRAL Rules on Transparency in Treaty-based Investor-State Arbitration (Rules on Transparency), which are in force since 1.4.2014.

${ }^{40}$ European Commission (2017), p. 15.

${ }^{41}$ Cf. www.uncitral.org/uncitral/en/uncitral_texts/arbitration/2014Transparency_Conventionstatus. html.

${ }^{42}$ European Parliament resolution (2013), para. 43.

${ }^{43}$ See, Art. 8.36, CETA, OJ L 11, p. 23, 14.1.2017; Art. 19, Chapter: Resolution of Investment Disputes, EU-Mexico Global Agreement (Draft agreed in principle on 21 April 2018); Art. 3.46, Chapter 3: Dispute Settlement, EU-Vietnam IPA (Draft for signature as of August, 2018).

${ }^{44}$ Recently, the Yukos-process has caused sensation here, where apparently the presiding arbitrator has transferred a large part of the actual tasks incumbent on himself to a co-worker. Cf. thereto Newman and Zaslowsky (2015).
} 
a further 100 days for the procedure before the Appellate Body (AB)), ${ }^{45}$ current investor-state arbitration proceedings are lengthy-and therefore cause considerable costs. In 2012, ICSID procedures took 5 years on average, ${ }^{46}$ while another study indicates an average duration for investment procedures of 3 years and 8 months. ${ }^{47}$

A permanent bench of judges with far-reaching powers to control the procedures could clearly contribute to the acceleration of proceedings, once the availability of the judges is assured. ${ }^{48}$ Furthermore, the implementation of a maximum duration for specific procedural stages should be considered in this context (see paras. 287 et seqq.).

\subsection{Advantages of the Two-Tiered MIC Option}

In the current discussion, a two-tiered MIC and a MIAM are principally, and for good reason, considered as alternative solutions. Both options are discussed in the following passages as both could constitute improvements in comparison to the existing system. However, certain arguments speak in favour of a two-tiered court $(\mathrm{MIC})^{49}$ as opposed to a standalone appeal mechanism (MIAM), even if the latter might, according to some literature, be easier to realise. ${ }^{50}$

Some scholars emphasise in particular that a standalone multilateral appellate body would not be sufficient to fully solve the legitimacy crisis of international investment law. ${ }^{51}$

In the long term, an MIC could develop a consistent interpretation of the overall system of investment protection standards and could lead to consistency and thus to legal certainty and predictability of decisions. ${ }^{52}$ Moreover, a particularly important difference of the MIAM solution relates to concerns with respect to ad hoc arbitrators, who are partly appointed by investors; they would still be the 'first instance' of such a MIAM system and thus would have the power to decide on the legality of

\footnotetext{
${ }^{45}$ Johannesson and Mavroidis (2016), pp. 12 et seq.

${ }^{46}$ Raviv (2014), p. 6.

${ }^{47}$ European Federation for Investment Law and Arbitration (2014), p. 8; Hodgson (2014). Cf. also European Commission (2015), p. 1: "The overall proceedings under the ICS, including appeal, are limited to 2 years (the Tribunal of First Instance must decide within 18 months and the Appeal Tribunal within 6 months). As a comparison, the average duration of proceedings under existing investment treaties is 3-4 years, with annulment or set-aside (for procedural grounds) potentially adding around another 2 years, meaning that the total length is often around 6 years (with many taking longer)."

${ }^{48}$ On this see also European Commission (2017), p. 58.

${ }^{49}$ See also Howse (2017), p. 233; European Union (2019), paras. 39 et seqq.

${ }^{50}$ Schill (2015), p. 8.

${ }^{51}$ Voon (2017), pp. 7 et seqq.; European Commission (2017), pp. 28 et seq.

${ }^{52}$ Schill (2015), p. 8; European Commission (2017), pp. 57 et seqq.; European Union (2019), paras. 44 et seqq.
} 
regulations by the state. This, in addition to the varying and thus inconsistent composition of the tribunals' benches, would remain a weak point, as these are considered to be the main reasons for inconsistency of decisions. The decisionmaking process of a permanent investment court may therefore be more 'morally binding, 53

67 Furthermore, a standing appellate mechanism may suspend decisions of the first instance tribunal, if those decisions were otherwise enforceable through the ICSID Convention or the New York Convention (NYC). This possibility of enforcement would likely be forgone when bringing an appeal before the appellate body. Regarding the appellate court solution, there is a risk that an appeals decision rendered by the MIAM would be undermined by its lack of enforceability in states not member to the MIAM.

68 The WTO Dispute Settlement System is often discussed in the context of the two-tiered solution, ${ }^{54}$ although —on closer examination - the WTO system rather constitutes a mixture of the two alternatives, since the adjudicators of the WTO's first instance panels are appointed $a d h o c$, and only after the dispute has emerged and not based on a predetermined composition. However, the institutional and procedural design of both the first instance (panel) and the second instance (Appellate Body) are defined as a whole in the Dispute Settlement Understanding (DSU) ${ }^{55}$ Therefore, a full adoption of the WTO System for the resolution of investment law disputes would entail that arbitrators of the first instance tribunal, administered by the MIC, be appointed ad hoc, whereas permanent, full-time judges would sit on the bench of the MIC's Appellate Body. ${ }^{56}$

69 Overall, the following chapters on the design of a two-tiered MIC and a MIAM will discuss the advantages as well as the challenges of the implementation of the respective solutions.

\section{References}

Alexandrov SA (2004) Breaches of contract and breaches of treaty - the jurisdiction of treaty-based arbitration tribunals to decide breach of contract claims in SGS v Pakistan and SGS v Philippines. J World Invest Trade 5:555-578

Alvarado Garzón AE (2019) Designing a multilateral investment court: blueprints for a new route in investor-state dispute settlement. ZEuS 22:475-500

\footnotetext{
${ }^{53}$ Cf. Schütze (2016), p. 15 on the advantages of institutional arbitration over ad hoc arbitration.

${ }^{54}$ See also Katz (2016), pp. 181 et seqq.; Alvarez Zarate (2018), pp. 2784 et seqq.; Ghori (2018), pp. 209 et seqq.

${ }^{55}$ Understanding on Rules and Procedures Governing the Settlement of Disputes, https://www.wto. org/english/tratop_e/dispu_e/dsu_e.htm.

${ }^{56}$ Most investment agreements which call for the establishment of an Appellate Tribunal provide for a permanent tribunal with permanent, full-time judges. On this see, Art. 3.10 EU-Singapore IPA (draft for signature), Art. 3.39 EU-Vietnam IPA (draft for signature) and Art. 12 EU-Mexico Global Agreement (draft for signature) as on February, 2019.
} 
Alvarez Zarate JM (2018) Legitimacy concerns of the proposed Multilateral Investment Court: is democracy possible. B C L Rev 59:2765-2790

Bastin L (2012) The Amicus Curiae in investor-state arbitration. Cambridge J Int Comp Law $1: 208-234$

Brower CN, Schill S (2009) Is arbitration a threat or a boom to the legitimacy of international investment law? Chicago J Int Law 9:471-498

Carver J (2004) How to avoid conflicting awards - the Lauder and CME case. J World Invest Trade 5:23-29

Chung O (2007) The lopsided international investment law regime and its effect on the future of investor-state arbitration. Va J Int Law 47:953-999

Douglas Z (2011) The MFN clause in investment arbitration: treaty interpretation off the rails. J Int Dispute Settlement 2:97-113

Eberhardt P (2014) Investitionsschutz am Scheideweg, TTIP und die Zukunft des globalen Investitionsrechts, Internationale Politikanalyse, May 2014

European Commission (2015) Why the new EU proposal for an Investment Court System in TTIP is beneficial to both States and investors, MEMO/15/6060 of 12.11.2015

European Commission (2017) Impact assessment - multilateral reform of investment dispute resolution, $\operatorname{SWD}(2017) 302$ final, 13.9.2017

European Federation for Investment Law and Arbitration (2014) TTIP consultation submission

European Parliament (2013) Resolution of 9.10.2013 on the EU-China negotiations for a bilateral investment agreement (2013/2674(RSP))

European Union (2017) Possible reform of investor-State dispute settlement (ISDS), Submission from the European Union, A/CN.9/WG.III/WP.145, 12 December 2017

European Union (2019) Possible reform of investor-State dispute settlement (ISDS), Submission from the European Union and its Member States, A/CN.9/WG.III/WP.159/Add.1, 24 January 2019

Franck SD (2009) Development and outcomes of investment treaty arbitration. Harv Int Law J 50:435-489

Gaillard E (2005) Establishing jurisdiction through a most-favoured-nation clause. N Y Law J 233 (105)

Gaukrodger D, Gordon K (2012) Investor-state dispute settlement, a scoping paper for the investment policy community. OECD Working Papers on International Investment 2012/03

Ghori U (2018) The International Investment Court System: the way forward for Asia. Int Trade Bus Law Rev 21:205-229

Griebel J, Kim Y (2007) Zwischen Aufbruch, Stillstand und Rückschritt - Überlegungen zur Zukunft des internationalen Investitionsrechts. SchiedsVZ, pp 186-195

Hindelang S (2015) Grundzüge eines modernen Investitionsschutzes - Ziele und Handlungsempfehlungen, Ein realpolitischer Vorschlag zur Reform des Investitionsschutzes zwischen CETA-Text und den Kommissionsvorschlägen zu TTIP, Harnack-Haus Reflections

Hodgson M (2014) Investment treaty arbitration: how much does it cost? How long does it take? Allen Overy Publications of 18.2.2014

Hodgson M (2015) Costs in investment treaty arbitration: the case for reform. In: Kalicki JE, Joubin-Bret A (eds) Reshaping the investor-state dispute settlement system: journeys for the 21st century. Brill, Leiden, pp 748-759

Howard DM (2017) Creating consistency through a World Investment Court. Fordham Int Law J 41:1-52

Howse R (2017) Designing a Multilateral Investment Court: issues and options. Yearb Eur Law 36 (1):209-236

Hueckel J (2012) Rebalancing legitimacy and sovereignty in international investment agreements. Emory Law J 61:601-640

Johannesson L, Mavroidis PC (2016) The WTO dispute settlement system 1995-2016: a data set and its descriptive statistics. EUI Working Paper RSCAS 2016/72 
Katz RL (2016) Modeling an International Investment Court after the World Trade Organization Dispute Settlement Body. Harv Negotiation Law Rev 22:163-188

Maupin JA (2011) MFN-based jurisdiction in investor-state arbitration: is there any hope for a consistent approach? J Int Econ Law 14:157-190

Newman LW, Zaslowsky D (2015) The Yukos case: more on the fourth arbitrator. New York Law Journal of 28.5.2015

Paparinskis M (2011) MFN clauses and international dispute settlement: moving beyond Maffezini and Plama. ICSID Rev 26:14-58

Paulsson J (2010) Moral hazard in international dispute resolution. ICSID Rev 25:339-355

Peterson LE (2001) Challenges under bilateral investment treaties give weight to calls for multilateral rules. World Trade Agenda 29(2001):12-14

Raviv A (2014) Achieving a faster ICSID. In: Reform of investor-state dispute settlement: in search of a roadmap. TDM 1(2014)

Schill S (2011) Enhancing international investment law's legitimacy: conceptual and methodological foundations of a new public law approach. Va J Int Law 52:57-102

Schill S (2015) Reforming Investor-State Dispute Settlement (ISDS): conceptual framework and options for the way forward. E15 Initiative

Schill S (2016) Maffezini v. Plama: reflections on the jurisprudential schism in the application of most-favored-nation clauses to matters of dispute settlement. In: Kinnear M, Fischer G, Minguez Almeida J, Torres LF, Uran Bidegain M (eds) Building international investment law: the first 50 years of ICSID. Wolters Kluwer, Alphen aan den Rijn. Chapter 18

Schill S (2017) Sind Regelungen Zur Investor-Staat-Streitbeilegung in EU-Freihandelsabkommen sinnvoll? Amsterdam Law School Research Paper No. 2017-06

Schreuer C (2004) Travelling the BIT route: of waiting periods, umbrella clauses and forks in the road. J World Invest Trade 5:231-256

Schütze RA (2016) Schiedsgericht und Schiedsverfahren, 6th edn. C.H. Beck, München

Sinclair AC (2004) The origins of the umbrella clause in the international law of investment protection. Arbitr Int 20:411-434

Steinbach A (2016) Investor-Staat-Schiedsverfahren und Verfassungsrecht. Rabels Zeitschrift für ausländisches und internationales Privatrecht 80(1):1-38

UNCITRAL (2018a) Possible reform of investor-State dispute settlement (ISDS) - Note by the Secretariat, A/CN.9/WG.III/WP.149, 5 September 2018

UNCITRAL (2018b) Report of Working Group III (Investor-State Dispute Settlement Reform) on the work of its thirty-sixth session (Vienna, 29 October-2 November 2018), A/CN.9/964, 6 November 2018

UNCITRAL (2018c) Possible reform of investor-State dispute settlement (ISDS) - cost and duration - Note by the Secretariat, A/CN.9/WG.III/WP.153, 31 August 2018

UNCITRAL (2019) Possible reform of investor-State dispute settlement (ISDS) - Third-party funding - Note by the Secretariat, A/CN.9/WG.III/WP.157, 24 January 2019

UNCTAD (2013) Reform of investor-state dispute settlement: in search of a roadmap. IIA Issues Note No. 2, June 2013

van Harten G (2008) A case for an international investment court. Society for International Economic Law, Conference Paper

van Harten G (2010) Perceived bias in investment treaty arbitration. In: Waibel M, Kaushal A, Chung $\mathrm{KH}$, Balchin $\mathrm{C}$ (eds) The backlash against investment arbitration: perceptions and reality. Kluwer Law International, Alphen aan den Rijn, pp 433-454

von Bogdandy A, Krenn C (2015) Zur Parlamentarisierung der Richterauswahl, Warum der Europarat der EU den Weg weist. In: Franzius C, Mayer FC, Neyer J (eds) Modelle des Parlamentarismus im 21. Jahrhundert, Neue Ordnungen von Recht und Politik. Verlagsgesellschaft mbH \& Co. KG, Bochum, pp 409-429

von Bogdandy A, Venzke I (2012) In whose name? An investigation of international courts' public authority and its democratic justification. Eur J Int Law 23:7-41 
Voon T (2017) Consolidating international investment law: the mega-regionals as a pathway towards multilateral rules. World Trade Rev 17(1):33-63

Wälde TW (2005) The "Umbrella" clause on investment arbitration - a comment on original intentions and recent cases. J World Invest Trade 6:183-236

Wuschka S (2015) Investitionsschiedsverfahren: Individualrechtsschutz oder "anti-demokratische Konzern-herrschaft"? Völkerrechtsblog of 20.4.2015

Wuschka S (2016) Investionsschiedsverfahren: Individualrechtsschutz oder "anti-demokratische Konzernherrschaft"? In: Buszewski SE, Martini S, Rathke H (eds) Freihandel vs. Demokratie, Grundsätze transnationaler Legitimation: Partizipation, Reversibilität, Transparenz. Nomos, Baden-Baden, pp 15-36

Open Access This chapter is licensed under the terms of the Creative Commons AttributionNonCommercial-NoDerivatives 4.0 International License (http://creativecommons.org/licenses/bync-nd/4.0/), which permits any noncommercial use, sharing, distribution and reproduction in any medium or format, as long as you give appropriate credit to the original author(s) and the source, provide a link to the Creative Commons licence and indicate if you modified the licensed material. You do not have permission under this license to share adapted material derived from this chapter or parts of it.

The images or other third party material in this chapter are included in the chapter's Creative Commons licence, unless indicated otherwise in a credit line to the material. If material is not included in the chapter's Creative Commons licence and your intended use is not permitted by statutory regulation or exceeds the permitted use, you will need to obtain permission directly from the copyright holder. 